\title{
Islet-1 promotes the proliferation and invasion, and inhibits the apoptosis of A375 human melanoma cells
}

\author{
XIAOLING ZHU ${ }^{1}$, YUZHEN $\mathrm{LI}^{2}$ and QINGGANG MENG ${ }^{3}$ \\ ${ }^{1}$ Department of Dermatology, The First Hospital of Harbin, Harbin, Heilongjiang 150010; \\ ${ }^{2}$ Department of Dermatology, The Second Affiliated Hospital of Harbin Medical University, Harbin, \\ Heilongjiang 150081; ${ }^{3}$ Department of Orthopaedic Surgery, The First Hospital of Harbin, \\ Harbin, Heilongjiang 150010, P.R. China
}

Received March 14, 2016; Accepted March 12, 2018

DOI: $10.3892 /$ ijmm.2018.3569

\begin{abstract}
The aim of this study was to examine the effects of the insulin gene enhancer-binding protein, islet-1 (ISL1), on the proliferation, invasion and apoptosis of the human melanoma cell line, A375. An ISL1 overexpression lentiviral vector was constructed and transfected into the A375 cells. The proliferation of the A375 cells transfected with the ISL1 vector (termed A375/ISL1 cells) was examined by MTT assay, flow cytometry and TUNEL assay, and cell invasion was examined by Transwell assay. The expression levels of matrix metalloproteinase (MMP)-2 and MMP-9 were measured by qPCR and western blot analysis; the expression levels of Akt and p-Akt were measured in the cells treated with vascular endothelial growth factor (VEGF) and the PI3K/Akt inhibitor, LY294002, by western blot analysis. The optical density value of the A375/ISL1 cells was increased after $12 \mathrm{~h}$ of culture $(\mathrm{P}<0.001)$, as shown by MTT assay. The ratio of apoptotic A375/ISL1 cells was significantly decreased $(\mathrm{P}<0.001)$, as shown by flow cytometry and TUNEL assay. In addition, the average penetration rate of the A375/ ISL1 cells significantly increased $(\mathrm{P}<0.001)$, as shown by Transwell assay. The expression levels of MMP-2 and MMP-9 were significantly increased in the A375/ISL1 cells, as shown by $\mathrm{qPCR}$ and western blot analysis $(\mathrm{P}<0.001)$. Moreover, treatment of the A375/ISL1 cells with VEGF for $48 \mathrm{~h}$ increased the expression of Akt and p-Akt compared with the control cells transfected with A375/green fluorescent
\end{abstract}

Correspondence to: Dr Qinggang Meng, Department of Orthopaedic Surgery, The First Hospital of Harbin, 151 Diduan Street, Daoli, Harbin, Heilongjiang 150010, P.R. China

Email: 1875199399@qq.com

*Contributed equally

Abbreviations: ISL1, islet-1; GFP, green fluorescent protein; MTT, 3-(4,5-dimethylthiazol-2-yl)-2,5-diphenyltetrazolium bromide

Key words: islet-1, proliferation, invasion, apoptosis, human melanoma protein (GFP) $(\mathrm{P}<0.05 ; \mathrm{P}<0.001$, respectively). In addition, in the A375/ISL1 cells treated with the LY294002 inhibitor for 24 and $48 \mathrm{~h}$, the level of Akt was also found to increase compared to the control A375/GFP cells $(\mathrm{P}<0.05)$. On the whole, the findings of this study indicate that the overexpression of ISL1 promotes the proliferation and invasion, and inhibits the apoptosis of A375 melanoma cells. ISL1 thus plays an important role in A375 cell survival, and these effects are possibly mediate via the PI3K/Akt signaling pathway.

\section{Introduction}

Melanoma is a highly malignant cutaneous neoplasm that involves the uncontrolled proliferation and migration of melanocytes (1). Under normal conditions, melanocytes reside at the bottom layer of the epidermis. Exposure to ultraviolet (UV) radiation triggers melanogenesis, with the pigment melanin providing protective effects against UV-induced damage (2). Although the causes of melanoma are unknown, DNA damage due to UV exposure and genetic predisposition may play a role in its pathogenesis. It has been estimated that approximately 76,100 patients in the USA will be diagnosed with melanoma in 2014, of which 9,710 will aquire malignant melanoma and succumb to the disease (3). Although localized melanoma can be treated by surgical resection, patients with distant metastases have an extremely poor prognosis. Therefore, the association between the pathogenesis of melanoma and biological targets has long been the focus of melanoma researchers.

The human insulin gene enhancer-binding protein islet-1 (ISL1) is a LIM homeodomain transcription factor that is encoded by the ISL1 gene (4). ISL1 plays an important role in embryogenesis and the differentiation of insulin-producing pancreatic $\beta$-cells within the islets of Langerhans (5). A previous study demonstrated that ISL1 could be utilized as a marker of cardiac progenitor cell lineage (6). Notably, in diagnostic surgical pathology, ISL1 has emerged as a valuable marker for well-differentiated pancreatic neuroendocrine tumors (pancreatic NETs) and their metastasis, particularly those with a small, round cell appearance, including small cell lung cancer, poorly differentiated neuroblastoma and Merkel cell carcinoma (7). In addition, some researchers have also studied some well-differentiated extrapancreatic neuroendo- 
crine neoplasms, such as thyroid medullary carcinomas and paragangliomas/pheochromocytomas, whose ISL1 status is not well known (8). However, to date, at least to the best of our knowledge, there is no stud available showing that ISL1 plays a role in the proliferation and invasion of melanoma.

Thus, the aim of the present study was to examine the effects of ISL1 on the proliferation, invasion and apoptosis of melanoma by infecting the ISL1 homeodomain overexpression lentiviral vector (LV5-ISL1 homo) into human melanoma A375 cells.

\section{Materials and methods}

Cell lines and culture. The human melanoma cell line, A375, and the packaging cell line, 293T, were purchased from the Cell Bank of Chinese Academy of Sciences (Shanghai, China) and cultured in RPMI-1640 and Dulbecco's modified Eagle's medium (DMEM) (both from Gibco Life Technologies, Carlsbad, CA, USA) supplemented with $10 \%$ fetal bovine serum (FBS) (Takara Biotechnology Co., Ltd., Dalian, China) and $1 \%$ penicillin-streptomycin $(100 \mu \mathrm{g} / \mathrm{ml}$; Invitrogen Life Technologies, Beijing, China) at $37^{\circ} \mathrm{C}$ with $5 \% \mathrm{CO}_{2}$.

In addition, the cells were treated with vascular endothelial growth factor (VEGF) at $100 \mu \mathrm{l}$ for 24 and $48 \mathrm{~h}$, or with the PI3K/Akt inhibitor, LY294002, at $100 \mu \mathrm{l}$ for 24 and $48 \mathrm{~h}$.

LV5-ISL1 homo construction and lentivirus packaging. Specific primers were designed using Primer Express software (Shenggong Biotech Co., Ltd., Shanghai, China), according to the nucleotide sequences of human ISL LIM homeobox 1 gene (Gene ID: 3670; https://www.ncbi.nlm.nih. gov/gene/3670). The primer sequences were as follows: ISLN forward, 5'-GATATGGCGGCCGCGCCACCATGGGAGA CATGGGAGATCCA-3' and reverse, 5'-GCTATGGGAT CCTCATGCCTCAATAGGACTGGCTACCATGC-3'. The CDS region of the ISLI gene was amplified using a PCR kit (Promega,Madison,WI,USA), according to the manufacturer's instructions. The target DNA gene fragment was subcloned into an LV5 lentiviral vector (Axygen Co., Shanghai, China) to construct the ISL1 homo overexpression lentiviral vector (LV5-ISL1 homo). The ISL1 fragment was identified by PCR with double digestion using Not I and BamHI and DNA sequencing.

Exponential 293T cells were seeded onto $10-\mathrm{cm}$ cell culture dishes with $2-2.5 \times 10^{6}$ cells/dish. The lentiviral vector packaged system of approximately $1,800 \mu \mathrm{l}$ in volume was added to the cells at density of $60-70 \%$. After the supernatant was collected, the high-concentration lentiviral concentrate was used to infect the 293T cells. The ratio of positive cells was determined by flow cytometry (FACSCanto II; BD Biosciences, San Diego, CA, USA), and the viral titer was detected by using a double dilution assay.

Lentiviral transfection of A375 cells. Exponential A375 cells were seeded onto 24 -well culture plates with $3-5 \times 10^{4}$ cells/well. The viral supernatant with the LV5-ISL1 homo and green fluorescent protein (GFP) were added respectively to the cells at a density of $70-80 \%$. After $72 \mathrm{~h}$, the transfection ratio was determined under a fluorescence microscope (BMI 3000; Leica, Wetzlar, Germany). The cell cultures with a transfection ratio of $>80 \%$ were used as the target cells and were identified by western blot analysis.

Three experimental groups were used in the present study, which included the ISL1 homo overexpression group (A375/ISL), empty vector group (A375/GFP), and control group (A375). All experiments were performed in triplicate at minimum.

\section{3-(4,5-Dimethylthiazol-2-yl)-2,5-diphenytetrazolium}

bromide (MTT) assay. Three groups of cells at a volume of $200 \mu \mathrm{l} /$ well (approximate density, $1 \times 10^{5}$ cells $/ \mathrm{ml}$ ) were seeded onto 96-well plates. At the culture time points of $6,12,24$, 48 and $56 \mathrm{~h}, 20 \mu \mathrm{l}$ of MTT (working concentration, $5 \mathrm{mg} / \mathrm{ml}$; Sigma-Aldrich, St. Louis, MO, USA) were added. The optical density value (OD value) of the cells was determined by spectrophotometry at a wavelength of $490 \mathrm{~nm}$ (GE Healthcare Life Sciences, Uppsala, Sweden).

Apoptosis detection by flow cytometry and TUNEL assay. At $48 \mathrm{~h}$ after transfection, cell apoptosis was analyzed using a flow cytometer with Annexin V-PE and 7-AAD staining. Annexin V-PE recognizes the externalization of phosphatidylserine by apoptotic cells, which usually indicates both early and late apoptosis. The cell-impermeant dye, 7-AAD, was also used as an indicator of cell membrane integrity. Double-negative staining cells were considered viable. Briefly, $100 \mu \mathrm{l}$ of the cell suspension collected from each sample was suspended in a mixture of $100 \mu \mathrm{l}$ Annexin V-PE and 7-AAD-binding buffer and then incubated at room temperature for $20 \mathrm{~min}$. The samples were analyzed using a flow cytometer (Guava EasyCyte 8HT; Millipore, Billerica, MA, USA). Apoptotic cells were visualized with $100 \mu 1$ 3'3-Diaminobenzidine (DAB; Boster Bioengineering Co., Ltd., Wuhan, China), which showed brown color. The cell population was separated into 3 groups: live cells with a low level of fluorescence, apoptotic cells in the earlier period with violet fluorescence, and the advanced-stage apoptotic cells with blue fluorescence (9).

A TUNEL kit (Red TUNEL kit, Roche, Mannheim, Germany) was used to detect cell apoptosis after $48 \mathrm{~h}$, following the manufacturer's instructions. Images were captured under a fluorescence microscope, and the percentage of positive cells was calculated using ImageJ software (National Institutes of Health, Bethesda, MD, USA). Four fields were randomly selected from each well of 12-well plates for the analysis. The index of apoptosis was calculated as the ratio of apoptotic cells and the total cells.

Cell cycle analysis. Cell cycle distribution was analyzed by flow cytometry. At $48 \mathrm{~h}$ after transfection, $1 \times 10^{6}$ cells were harvested by typsinization, rinsed with phosphate-buffered saline (PBS), and fixed with cold $70 \%$ ethanol at $4^{\circ} \mathrm{C}$ overnight. The cells were then washed twice with PBS and re-suspended in $1 \mathrm{ml}$ of staining solution $(50 \mu \mathrm{g} / \mathrm{ml}$ propidium iodide (PI), $50 \mu \mathrm{g} / \mathrm{ml}$ RNase A, and $0.1 \%$ Triton X-100 in citrate buffer, $\mathrm{pH}$ 7.8), and incubated at room temperature for $30 \mathrm{~min}$, as previously described (10). The cells were captured using a fluorescence microscope (BMI 3000; Leica) and the percentage of cells at each stage of the cell cycle was analyzed by flow cytometry (FACSCanto II; BD Biosciences). 
Table I. Primer sequences.

\begin{tabular}{llc}
\hline $\begin{array}{l}\text { Gene } \\
\text { name }\end{array}$ & \multicolumn{1}{c}{$\begin{array}{c}\text { Primer } \\
\text { sequence }\end{array}$} & $\begin{array}{c}\text { Product } \\
\text { size (bp) }\end{array}$ \\
\hline$M M P-2$ & F: 5'-TTTGACGGTAAGGACGGACTC-3' & 146 \\
& R:5'-TACTCCCATCGGCGTTC-3' & \\
MMP-9 & F: 5'-CGAACTTTGACAGCGACAAGA-3' & 214 \\
& R:5'-TCAGGGCGAGGACCATAGAG-3' & \\
3-actin & F: 5'-TGACGTGGACATCCGCAAAG-3' & 102 \\
& R:5'-CTGGAAGGTGGACAGCGAGG-3' & \\
\hline
\end{tabular}

F, forward; R, reverse; MMP, matrix metalloproteinase.

Transwell ${ }^{\circledR}$ invasion assay. Transwell ${ }^{\circledR}$ filters (Corning Costar, Cambridge, MA, USA) were coated with Matrigel $^{\circledR}(3.9 \mu \mathrm{g} / \mu \mathrm{l}$, 60-80 $\mu \mathrm{l})$. Three groups of cells were resuspended in $100 \mu \mathrm{l}$ of serum-free RPMI-1640 medium and added to the upper compartment of the chambers. The cells migrating from the Matrigel ${ }^{\circledR}$ into the pores of the inserted filter were fixed with $100 \%$ methanol and stained with hematoxylin. The positive cells in 3 randomly selected visual fields were counted using an inverted microscope (CKX41; Olympus, Tokyo, Japan).

Quantitative polymerase chain reaction $(q-P C R)$. $\mathrm{qPCR}$ was used to quantify differences in matrix metalloproteinase (MMP)-2 and MMP-9 mRNA expression levels among the 3 groups. Total RNA was extracted using TRIzol reagent (Takara Bio, Inc., Otsu, Japan), following the manufacturer's instructions. In this procedure, we used the prepared cDNA, Power SYBR-Green Master Mix (Applied Biosystems, Warrington, UK), and primers of the human MMP-2, MMP-9, and $\beta$-actin genes (1:1,000; Cell Signaling Technology, Inc., Danvers, MA, USA). All the experiments were repeated 3 times. The primer sequences used in the present study are listed in Table I. Each PCR reaction contained $0.5 \mu \mathrm{l}$ of SYBR-Green, $20.5 \mu \mathrm{l}$ of molecular grade water, $2 \mu \mathrm{l}$ of each forward and reverse primer, and $2 \mu \mathrm{l}$ of cDNA. Amplification was performed using the following conditions: $94^{\circ} \mathrm{C}$ for $4 \mathrm{~min}$, $94^{\circ} \mathrm{C}$ for $20 \mathrm{sec}, 60^{\circ} \mathrm{C}$ for $30 \mathrm{sec}$, and 35 cycles at $72^{\circ} \mathrm{C}$ for $30 \mathrm{sec}$. These signals were determined at $72^{\circ} \mathrm{C}$. qPCR was performed under standard conditions, and all experiments were conducted in triplicate. Relative MMP-2 and MMP-9 mRNA expression levels were compared among the 3 groups. The qPCR data were analyzed using the comparative cycle threshold (CT) method (11). A difference in $\mathrm{CT}(\Delta \mathrm{CT})$ was determined as the diversities of MMP-2 and MMP-9 mRNA expression levels among different groups. $\Delta \Delta \mathrm{CT}$ was calculated by calculating the difference between A375/ISL group and the other 2 groups.

Western blot analysis. Total protein was extracted from the 3 groups of cells using $0.1 \mathrm{ml}$ RIPA lysis buffer [50 mM Tris ( $\mathrm{pH} 7.4$ ), $150 \mathrm{mM} \mathrm{NaCl}, 1 \% \mathrm{NP}-40,0.5 \%$ sodium deoxycholate]. Approximately $30 \mu \mathrm{g}$ of protein was subjected to $10 \%$ SDS-PAGE and then transferred onto nitrocellulose membranes (Whatman, Pittsburgh, PA, USA). The membranes with electrophoresed proteins were incubated with primary

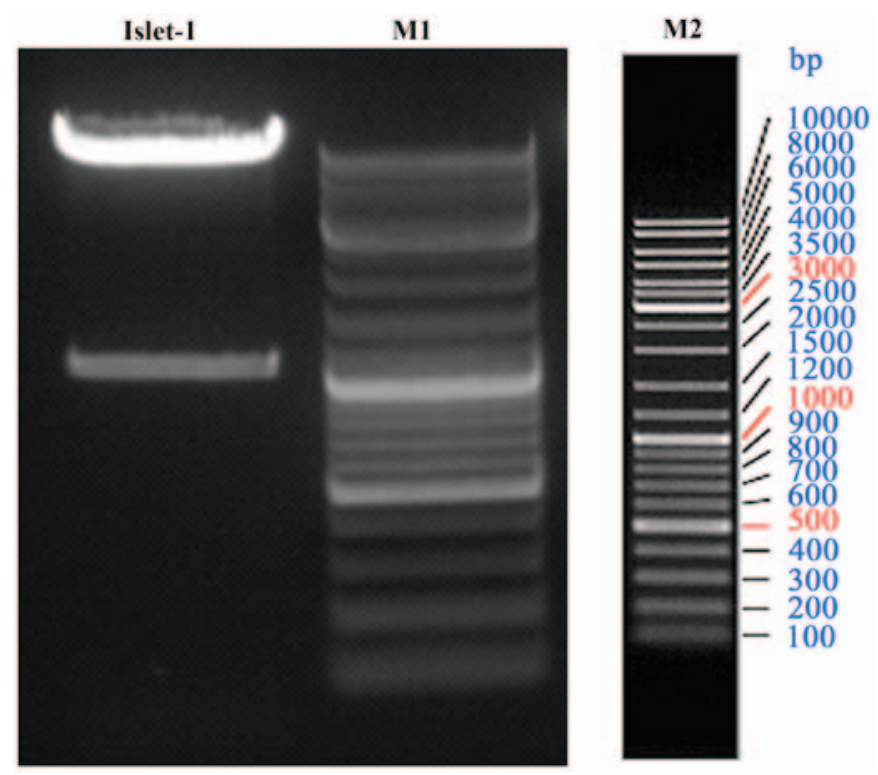

Figure 1. PCR products of homeodomain overexpression lentiviral vector (LV5-ISL1 homo) on 1\% agarose gel electrophoresis. Expression of LV5-ISL1 homo was constructed and identified by PCR with double digestions using the endonucleases, NotI and BamHI. A single fragment was visualized as a band of approximately $39 \mathrm{kDa}$ in size. M, marker; Fermentas SM0331.

antibodies against MMP-2, MMP-9 and ISL1 (dilution 1:800; Cell Signaling Technology, Inc.) and against Akt and p-Akt (Sigma-Aldrich). The secondary antibodies used were goat anti-rabbit IgG HRP and goat anti-mouse IgG HRP (both from Sigma-Aldrich). The antigen-antibody reaction was visualized by using ultra-enhanced chemiluminescence western blotting detection reagents (Sigma-Aldrich). Moreover, the protein expression levels of Akt $(1: 1,000)$ and p-Akt $(1: 1,000)$ (both from Cell Signaling Technology, Inc.) were measured at 24 and $48 \mathrm{~h}$ in the A375/ISL and A375/GFP cells by western blot analysis. GAPDH (1:5,000; Abcam, Cambridge, UK) was used as the internal reference. Gray value ratios in the bar charts were quantified using the quantities of western blot analysis.

Statistical analysis. The data were analyzed using SPSS software 11.5 (SPSS, Inc., Chicago, IL, USA). One-way analysis of variance (ANOVA) was conducted to investigate differences within the groups for quantitative variables with the Dunnett's post hoc test for multiple comparisons. P-values $<0.05$ were considered statistically significant, and P-values $<0.01$ were designated as highly significant.

\section{Results}

Construction of LV5-ISL1 homo and cell transfection. The LV5-ISL1 homo vector was constructed and identified by PCR and DNA sequencing. PCR analysis revealed a single band of approximately $39 \mathrm{kDa}$ in size in a $1 \%$ agarose gel (Fig. 1). DNA sequencing confirmed that the recombinant plasmid contained the ISL1 gene fragment. The LV5-ISL1 homo with a viral titer of $5.0 \times 10^{8} \mathrm{TU} / \mathrm{ml}$ was used to transfect the human melanoma A375 cells. Green fluorescence in the infected A375 cells, as visualized under fluorescence optics indicated 

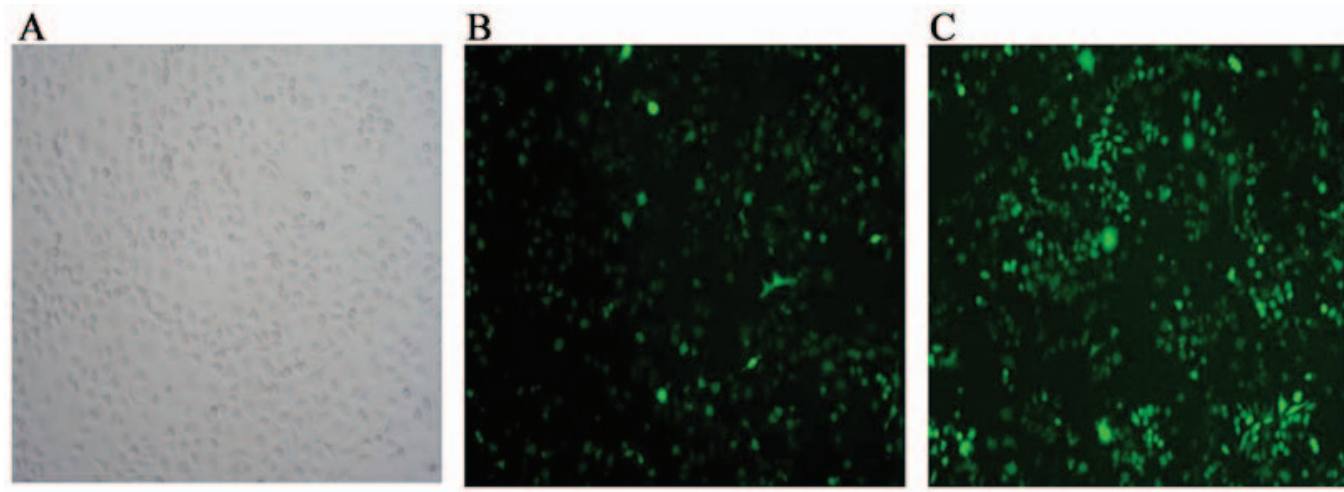

Figure 2. Transfection efficiency of LV5-ISL1 homo in A375 cells. The expression of green fluorescence observed in A375 cells confirmed successful transfection. (A) Untransfected A375 cells (A375); (B) A375 cells transfected with green fluorescent protein (GFP) (A375/GFP); (C) A375 cells transfected with LV5-ISL1 homo (A375/ISL) (x200 magnification).

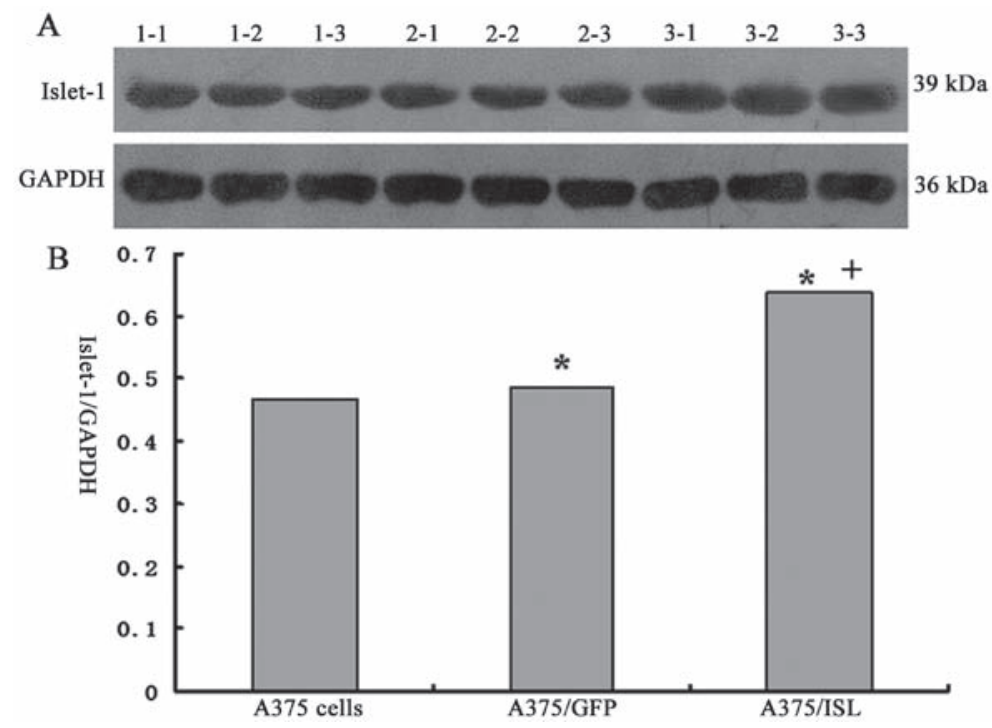

Figure 3. Western blot analysis of insulin gene enhancer-binding protein (ISL1). (A and B) Expression level of ISL1 was significantly increased in A375/ISL cells compared to that in the A375/green fluorescent protein (GFP) ( $\mathrm{P}<0.05)$ and $\mathrm{A} 375$ cells $(+\mathrm{P}<0.001)$. There were 3 specimens in each group, A375/ISL (lanes 3-1, 3-2 and 3-3); A375/GFP (lanes 2-1, 2-2 and 2-3); A375 (lanes 1-1, 1-2 and 1-3).

successful transfection (Fig. 2). The results of western blot analysis also revealed that ISL1 expression was significantly increased in the A375/ISL cells compared with the A375/GFP and A375 cells (Fig. 3A and B).

Promoting effects of ISL1 on the proliferation of A375 cells. To examine the effects of ISL1 on the proliferation of A375 cells, the viability of the transfected and untransfected A375 cells was examined at $6,12,24,48$ and $56 \mathrm{~h}$ by MTT assay. As shown in Fig. 4 and Table II, the OD value of the A375/ ISL cells was higher than that of the A375/GFP and A375 cells following culture for $6 \mathrm{~h}(\mathrm{P}<0.001)$, and the difference was more conspicuous with a longer culture time $(\mathrm{P}<0.001$ for $12,24,48$ and $56 \mathrm{~h}$ ). No statistical differences were observed at the various time points between the A375/GFP and $\mathrm{A} 375$ cells $(\mathrm{P}>0.05)$. These results suggested that ISL1 promotes the proliferation of A375 cells.

Effects of ISLI on the apoptosis of A375 cells. Flow cytometry using Annexin V-PE and 7-AAD staining was conducted

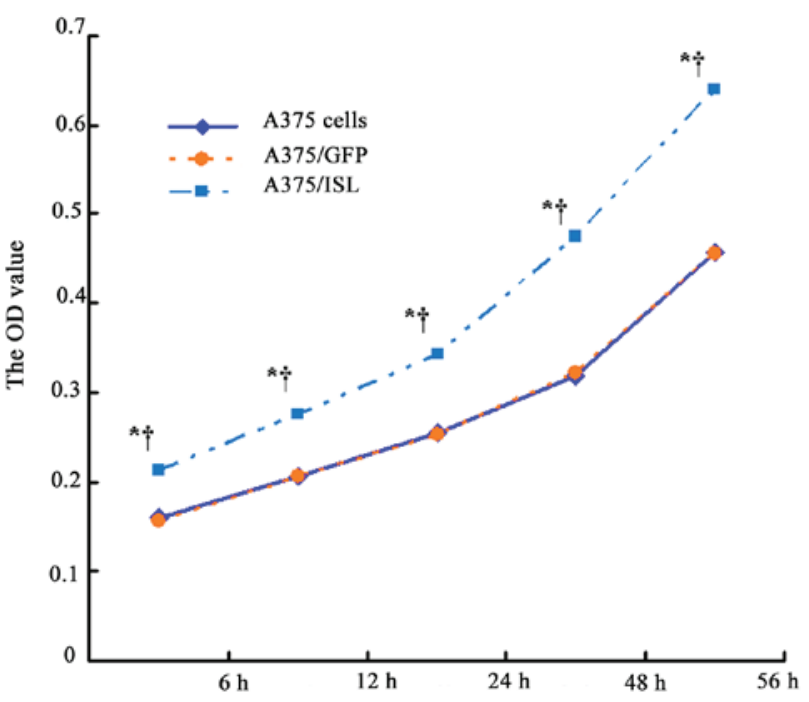

Figure 4. Optical density (OD) value comparison of 3 groups of A375 cells by MTT assay. Expression of OD value of the A375/ISL cells was higher than that of A375/green fluorescent protein (GFP) and A375 cells at 6, 12, 24, 48 and $56 \mathrm{~h}$ after transfection ( $\left.{ }^{*} \mathrm{P}<0.001\right)$. 
Table II. Optical density of the 3 groups of A375 cells following culture for 6, 12, 24, 48 and $56 \mathrm{~h}$.

Optical density value at different time points

\begin{tabular}{|c|c|c|c|c|c|}
\hline Cells & $6 \mathrm{~h}$ & $12 \mathrm{~h}$ & $24 \mathrm{~h}$ & $48 \mathrm{~h}$ & $56 \mathrm{~h}$ \\
\hline A375 & $0.1593 \pm 0.0010$ & $0.2063 \pm 0.0047$ & $0.2539 \pm 0.0034$ & $0.3183 \pm 0.0030$ & $0.4572 \pm 0.0091$ \\
\hline A375/GFP & $0.1556 \pm 0.0061$ & $0.2054 \pm 0.0058$ & $0.2526 \pm 0.0136$ & $0.3221 \pm 0.0147$ & $0.4565 \pm 0.0071$ \\
\hline A375/GSN & $0.2133 \pm 0.0033$ & $0.2750 \pm 0.0065$ & $0.3439 \pm 0.0097$ & $0.4745 \pm 0.0087$ & $0.6392 \pm 0.0022$ \\
\hline $\mathrm{P}_{1}$ & 0.480 & 0.975 & 0.979 & 0.861 & 0.986 \\
\hline $\mathrm{P}_{2}$ & $<0.001$ & $<0.001$ & $<0.001$ & $<0.001$ & $<0.001$ \\
\hline $\mathrm{P}_{3}$ & $<0.001$ & $<0.001$ & $<0.001$ & $<0.001$ & $<0.001$ \\
\hline
\end{tabular}

Data are the means $\pm \mathrm{SD}$; statistical difference was analyzed by one-way ANOVA. From 6 to $56 \mathrm{~h}:(\mathrm{t}=1.1038, \mathrm{P}=0.480),(\mathrm{t}=0.1858, \mathrm{P}=0.975)$, $(\mathrm{t}=0.1701, \mathrm{P}=0.979),(\mathrm{t}=0.4615, \mathrm{P}=0.861)$ and $(\mathrm{t}=0.1385, \mathrm{P}=0.986)$ between $\mathrm{A} 375 / \mathrm{GFP}$ and $\mathrm{A} 375 ;(\mathrm{t}=16.2565, \mathrm{P}<0.001),(\mathrm{t}=14.7336, \mathrm{P}<0.001)$, $(\mathrm{t}=11.2021, \mathrm{P}<0.001),(\mathrm{t}=19.1430, \mathrm{P}<0.001)$ and $(\mathrm{t}=32.8868, \mathrm{P}<0.001)$ between A375/GSN and A375; $(\mathrm{t}=17.3603, \mathrm{P}<0.001),(\mathrm{t}=14.9194, \mathrm{P}<0.001)$, $(\mathrm{t}=11.3722, \mathrm{P}<0.001),(\mathrm{t}=18.6815, \mathrm{P}<0.001)$ and $(\mathrm{t}=33.0253, \mathrm{P}<0.001)$ between A375/ISL and A375/GFP. A375/GFP vs. A375, $\mathrm{P}_{1}>0.05 ; \mathrm{A} 375 / \mathrm{GSN}$ vs. A375, $\mathrm{P}_{2}<0.01 ; \mathrm{A} 375 / \mathrm{ISL}$ vs. A375/GFP, $\mathrm{P}_{3}<0.01$. GFP, green fluorescent protein.
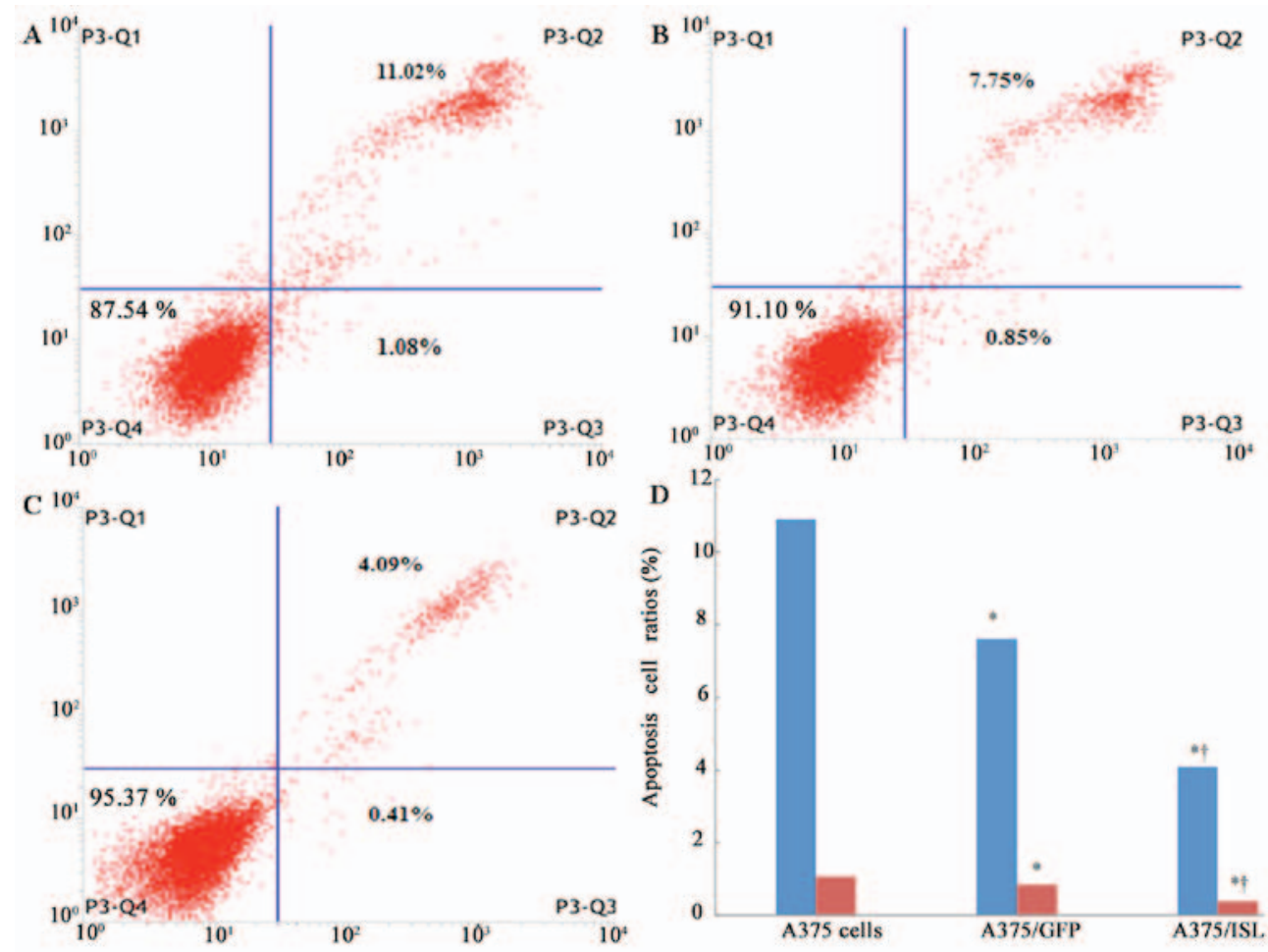

Figure 5. Expression of effect of insulin gene enhancer-binding protein (ISL1) on apoptosis of A375 cells. ISL1 on apoptosis of A375 cells as determined by flow cytometry with Annexin V-PE and 7-AAD staining. There were 3 groups of viable A375 cells (A, A375 cells; B, A375/GFP cells; and C, A375/ISL cells) as determined by flow cytometry. (D) Expression of ratio of apoptotic cells in the A375/ISL group was significantly lower than that of the A375/GFP and A375 groups (" $\mathrm{P}<0.05$ and $\left.{ }^{\dagger} \mathrm{P}<0.001\right)$. Q1, dying cells; Q2, late apoptotic cells; Q3, viable apoptotic cells; Q4, normal active cells.

to estimate cell apoptosis at $48 \mathrm{~h}$ following transfection. As shown in Fig. 5, the number of viable cells in the A375 and A375/GFP groups was 87.54 and $91.10 \%$, respectively (Fig. 5A and B), whereas the A375/ISL cells exhibited an increase in viability to $95.37 \%$ (Fig. 5C). Moreover, the ratio of apoptotic cells in the A375/ISL group (4.50\%) was significantly lower than that in the A375/GFP (8.60\%) and A 375 (12.10\%) groups (Fig. 5D; P<0.001). No statistically significant difference in the ratios between the A375/GFP and A375 cells was observed $(\mathrm{P}=0.066)$. These findings suggested that ISL1 markedly inhibited the apoptosis of the
A375 cells. To verify this observation, we used the sections of TUNEL staining with brown DAB (Boster Bioengineering Co., Ltd.). As shown in Fig. 6, a small of TUNEL-positive cells in the A375/ISL group were observed, whereas several cells were stained brown in the A375/GFP and A375 groups (Fig. 6A-C). Furthermore, the number of TUNEL-positive cells was

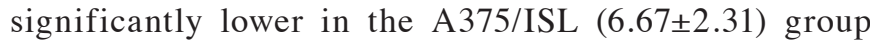
compared with the A375/GFP (40.67 \pm 4.73$)$ and A375 group s $(20.33 \pm 6.66)(\mathrm{P}<0.001)$. No statistically significant difference in the ratios between the A375/GFP and A375 cells was observed ( $P=0.073$; Fig. 6D). 


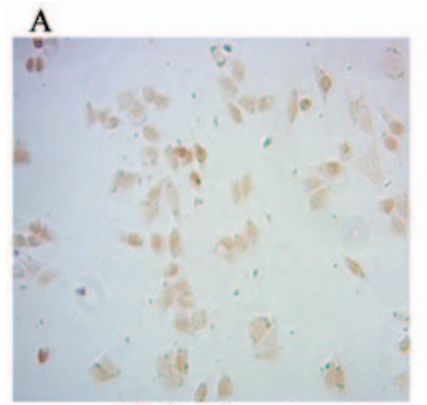

A375 cells
B

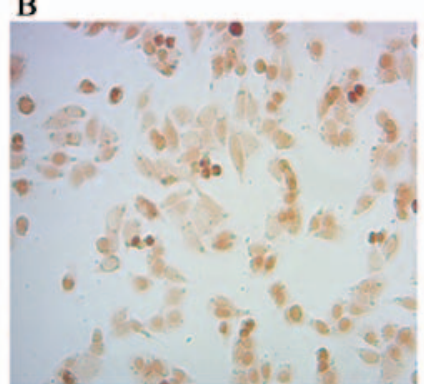

A375/GFP
C

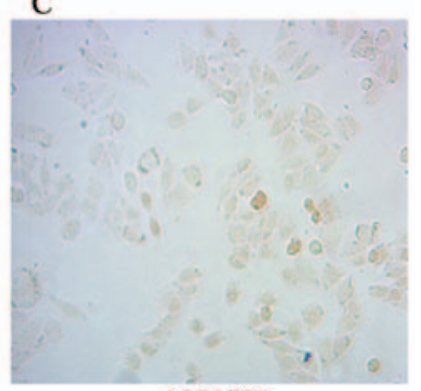

A375/ISL

D

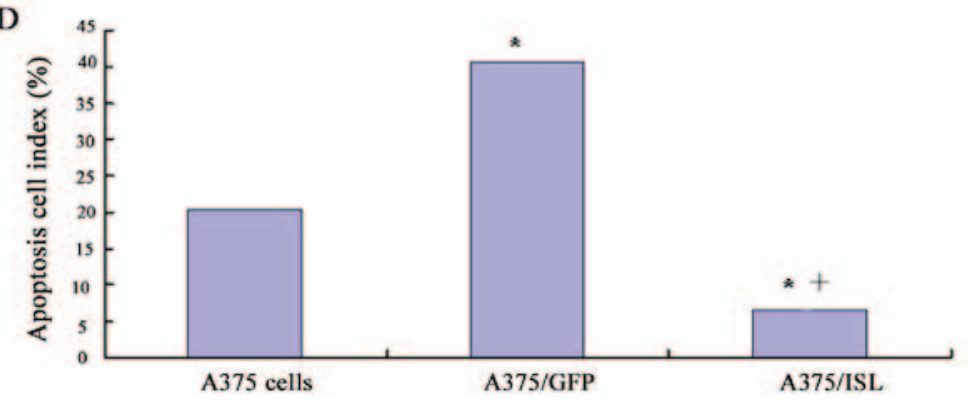

Figure 6. Effects of overexpression of insulin gene enhancer-binding protein (ISL1) on the apoptosis of A375 cells determined by TUNEL assay. (A-C) A small amount of TUNEL-positive cells was detected in the A375/ISL group, whereas several cells were stained in the A375/green fluorescent protein (GFP) and A375 cells groups (x200 magnification). (D) The number of TUNEL-positive cells was significantly lower in the A375/ISL group compared to the A375/ GFP and $\mathrm{A} 375$ groups ( $\mathrm{P}<0.05$ and $\left.{ }^{+} \mathrm{P}<0.001\right)$.
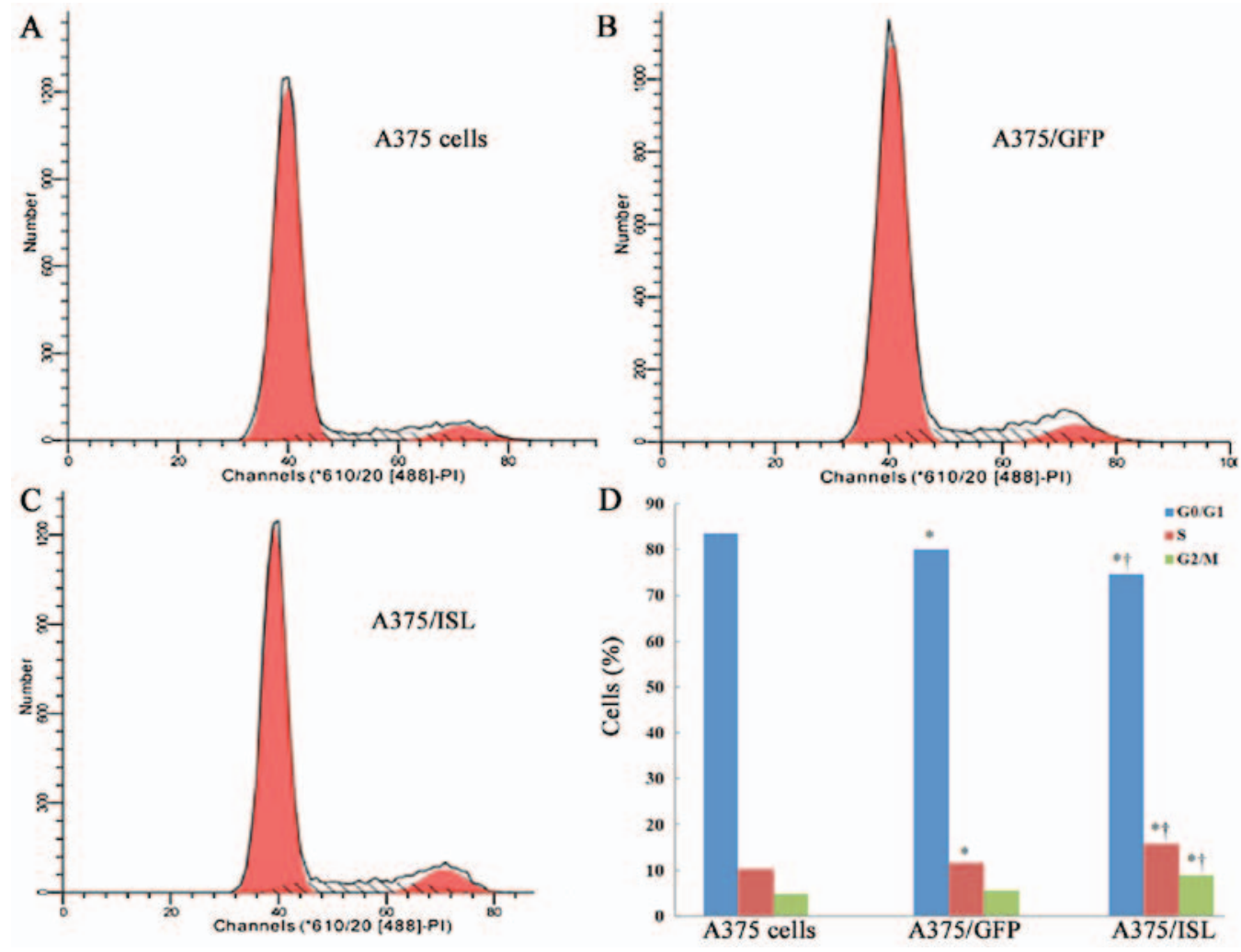

Figure 7. Effect of overexpression of insulin gene enhancer-binding protein (ISL1) on cell cycle distribution in A375 cells. (A-C) Percentages of cells in the G0/ $\mathrm{G} 1, \mathrm{~S}$ and G2/M phases were calculated in the 3 groups of A375 cells at $48 \mathrm{~h}$ by flow cytometry. (D) Compared to the A375/green fluorescent protein (GFP) and A375 cells, the A375/ISL cells were significantly enriched in the S phase and depleted in the G0/G1 phase ( ${ }^{*} \mathrm{P}<0.05$ and ${ }^{\dagger} \mathrm{P}<0.001$ ).

ISL1 induces G1 arrest in the A375 cells. To investigate the mechanisms responsible for the inhibitory effects of ISL1 on the apoptosis of A375 cells, we first examined its effects on cell cycle progression by flow cytometry. The percentages of cells in the $\mathrm{G0} / \mathrm{G} 1, \mathrm{~S}$ and $\mathrm{G} 2 / \mathrm{M}$ phases in the 3 groups of A375 cells at $48 \mathrm{~h}$ are shown in Fig. 7. Compared to the A375/GFP and 


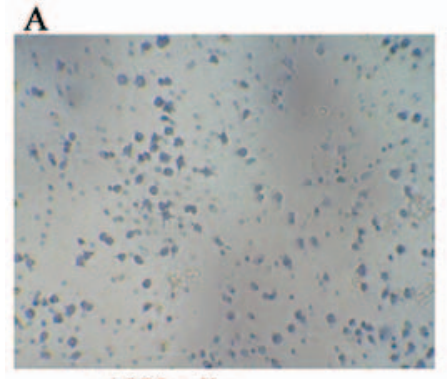

A375 cells
B

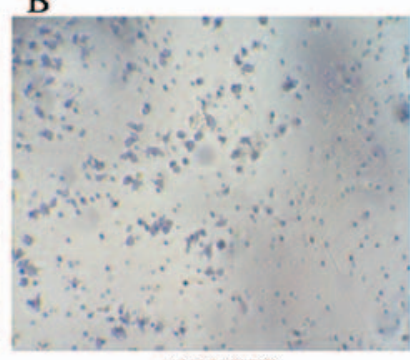

A375/GFP

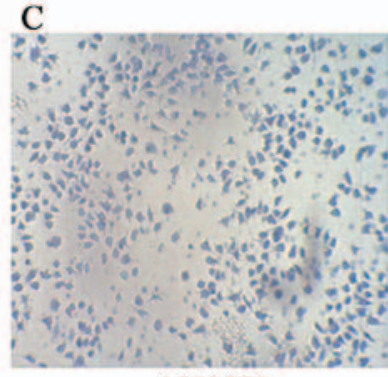

A375/ISL

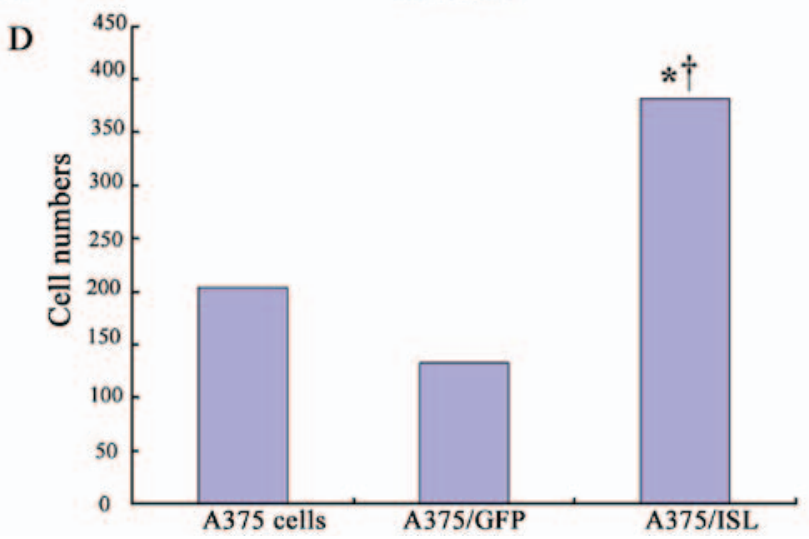

Figure 8. Transwell invasion assay was used to examine the penetration rate of the 3 groups of A375 cells. A greater number of A375/ISL cells penetrated the Matrigel compared to the A375/green fluorescent protein (GFP) and A375 cells (A, A375 cells; B, A375/GFP cells; and C, A375/ISL cells; magnification, x400). (D) The average penetration rate/cell number of the A375/ISL cells was significantly higher than that of the A375/GFP and A375 cells (" $\mathrm{P}<0.05$ and ${ }^{\dagger} \mathrm{P}<0.001$ ), as indicated by the Transwell invasion assay.

A375 cells, the percentage of A375/ISL cells in S phase was significantly increased, while that in the G0/G1 phase was decreased $(\mathrm{P}<0.001 ;$ Fig. 7D). These findings indicate that ISL1 may play a role in promoting the proliferation of A375 cells.

Effects of ISL1 on the invasive capacity of A375 cells. We examined the effects of ISL1 on the capacity of A375 cells to undergo invasion by using penetration experiments on Transwell chambers coated with Matrigel. The cells exhibiting an invasive ability will digest the Matrigel and penetrate the $8-\mu \mathrm{m}$ pores on the polycarbonate membrane. In the present study, a higher number of A375/ISL cells penetrated the Matrigel compared to that observed with the A375/GFP and A375 cells (Fig. 8). The average penetration rate of the A375/ISL cells $(381.50 \pm 21.98)$ was significantly higher than that of the A375/GFP cells (134.00 \pm 37.07$)$ and A375 cells (204.75 \pm 62.74$)$ $(\mathrm{P}=0.001 ; \mathrm{P}<0.001$, respectively). No statistically significant differences in the average penetration rate between the A375/ GFP and A375 cells were observed ( $\mathrm{P}=0.086$; Fig. 8D).

Effects of ISL1 on the expression levels of MMP-2 and MMP-9. The mRNA expression levels of MMP-2 and MMP-9 were found to increase in the transfected A375 cells compared with the untransfected A375 cells, as indicated by qPCR analysis. As shown in Fig. 9, the mRNA expression levels of MMP-2 and MMP-9 significantly increased in the A375/ISL cells $(0.0750 \pm 0.0085$ and $0.0394 \pm 0.0041)$, and these levels were markedly higher than those in the A375/ GFP cells $(0.0251 \pm 0.0031$ and $0.0129 \pm 0.0022$, respectively) and the A375 cells $(0.0215 \pm 0.0012$ and $0.0121 \pm 0.0012$, respectively) at $48 \mathrm{~h}$ after transfection, with a significant difference

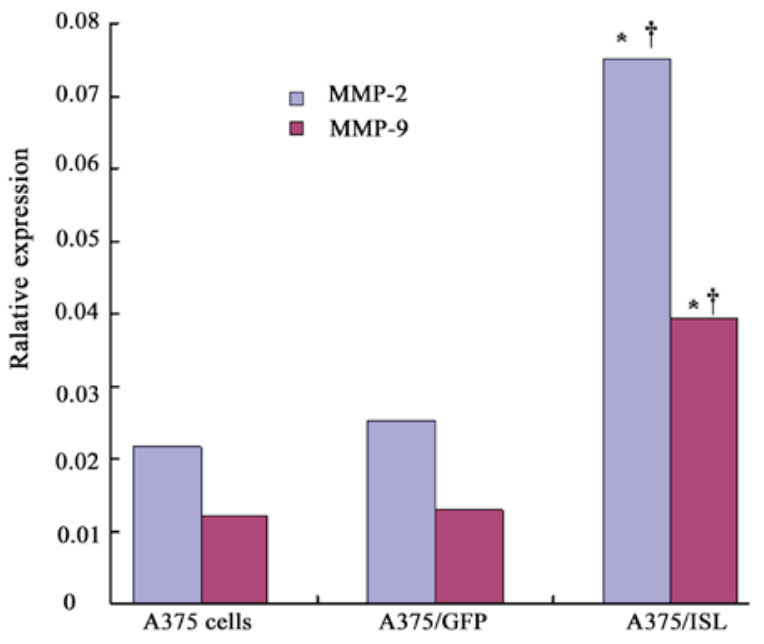

Figure 9. Effects of insulin gene enhancer-binding protein (ISL1) on the mRNA expression levels of matrix metalloproteinase (MMP)-2 and MMP-9. The mRNA expression levels of MMP-2 and MMP-9 were examined by qPCR The mRNA expression of MMP-2 and MMP-9 was markedly increased in the A375/ISL cells, with a significant difference observed between the A375/ISL and A375/green fluorescent protein (GFP) cells ( $\left.{ }^{*} \mathrm{P}<0.001\right)$ and between the A375/ISL and A375 cells $(\mathrm{P}<0.001)$ using one-way ANOVA.

observed between the A375/ISL and A375/GFP cells $(\mathrm{P}<0.001)$ and between the A375/ISL and A375 cells $(\mathrm{P}<0.001)$, as shown by one-way ANOVA. However, no statistically significant differences were observed between the A375/GFP and A375 cells (Fig. 9; P>0.05).

To further confirm the effects of ISL1 on the protein expression of MMP-2 and MMP-9, western blot analysis 

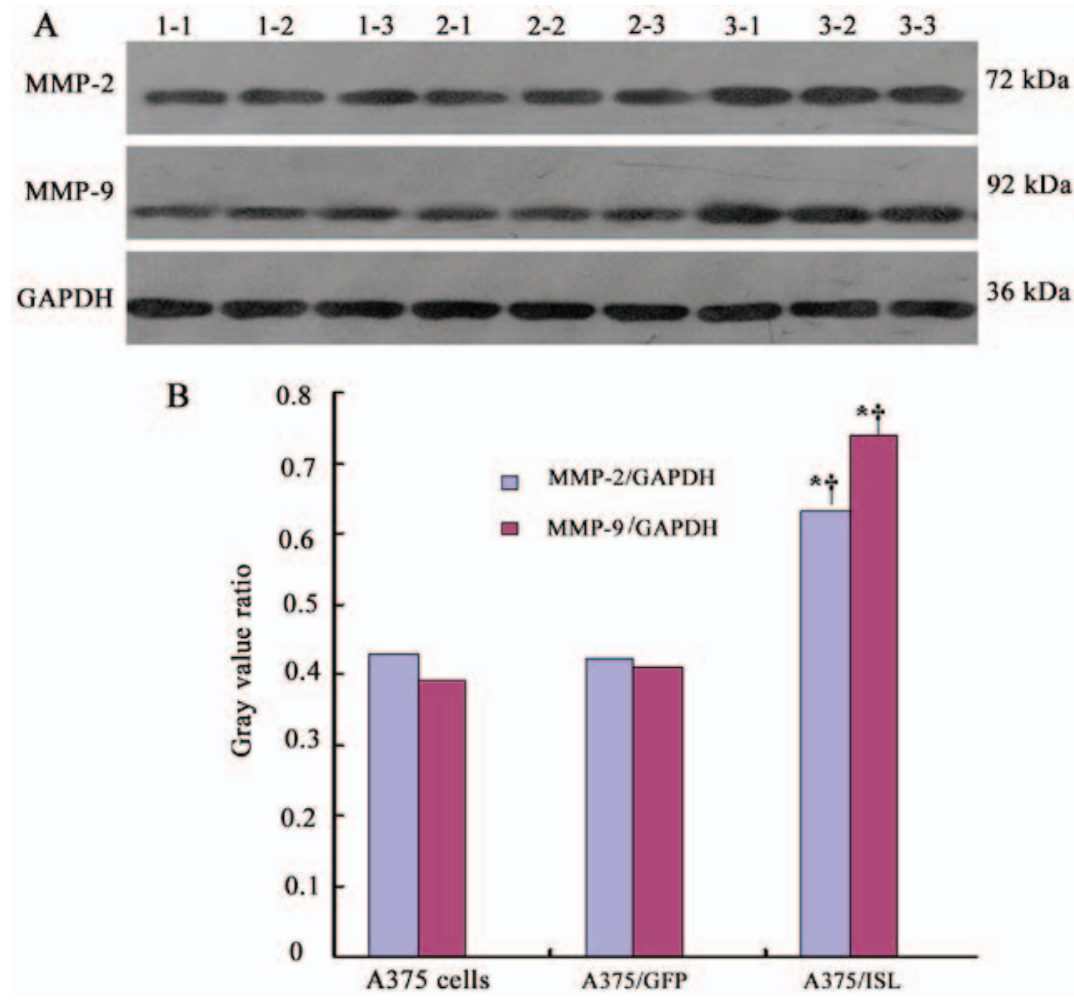

Figure 10. Effects of insulin gene enhancer-binding protein (ISL1) on the protein expression levels of matrix metalloproteinase (MMP)-2 and MMP-9. (A) Protein expression of MMP-2 and MMP-9 was examined by western blot analysis. (B) Protein expression of MMP-2 and MMP-9 was markedly increased in the A375/ISL cells, with significant differences between the A375/ISL group and the other 2 groups ( $\mathrm{P}<0.001)$. There were 3 specimens in each group, A375/ ISL (lanes 3-1, 3-2 and 3-3); A375/green fluorescent protein (GFP) (lanes 2-1, 2-2 and 2-3); and A375 (lanes 1-1, 1-2 and 1-3) (*..P<0.001).

was performed (Fig. 10A). In the A375/ISL cells, the protein expression levels of MMP-2 and MMP-9 were markedly increased. Significant differences were observed between the A375/ISL cells and the other 2 groups (A375/ISL vs. A375/ GFP, $\mathrm{P}<0.001$ for MMP-2 and $\mathrm{P}<0.001$ for MMP-9; A375/ISL vs. A375, $\mathrm{P}<0.001$ for MMP-2 and $\mathrm{P}<0.001$ for MMP-9). No statistically significant differences were observed between the A375/GFP and A375 cells ( $\mathrm{P}=0.843$ for MMP-2, $\mathrm{P}=0.452$ for MMP-9; Fig. 10B).

Effect of ISLI on the activation of the Akt pathway. We wished to determine whether ISL1 exerts its effects on the A375 melanoma cells via the Akt pathway. Thus, we examined the levels of Akt and p-Akt in the 3 groups of cells by western blot analysis. The cells were also treated with VEGF or the PI3K/ Akt inhibitor, LY294002. As shown in Fig. 11, treatment of the A375/ISL cells with VEGF for $48 \mathrm{~h}$ led to a significant increase in the levels of Akt and p-Akt. The levels of Akt and p-Akt in the A375/ISL cells treated with VEGF for $48 \mathrm{~h}$ were significantly higher compared with those in the A375/ GFP cells (Akt: A375/ISL cells, $0.7838 \pm 0.0243$ vs. A375/ GFP cells, 0.6554 $\pm .0346, \mathrm{P}<0.05$; Fig.11A; p-Akt: A375/ISL cells, 0.7975 \pm 0.0331 , vs. A375/GFP cells, 0.5088 \pm 0.0437 , $\mathrm{P}<0.001$, Fig. 11B). No statistically significant differences were observed in the levels of Akt and p-Akt between the A375/ISL and A375/GFP cells treated with VEGF for $24 \mathrm{~h}(\mathrm{P}>0.05)$.

In addition, treatment of the A375/ISL cells with the inhibitor, LY294002, for 24 and $48 \mathrm{~h}$ also significantly increased the levels of Akt compared with the A375/GFP cells (A375/ISL cells $24 \mathrm{~h}, 0.9127 \pm 0.0276$ and $48 \mathrm{~h}, 0.9502 \pm 0.0290$; A375/GFP cells $24 \mathrm{~h}, 0.9088 \pm 0.0312$ and $48 \mathrm{~h}, 0.8747 \pm 0.0265 ; \mathrm{P}<0.05$, Fig. 11A). Conversely, no statistically significant differences in the levels of p-Akt were observed between the A375/ISL and A375/GFP cells treated with LY294002 inhibitor for 24 and $48 \mathrm{~h}(\mathrm{P}>0.05$, Fig. 11C).

\section{Discussion}

Cutaneous malignant melanoma (CMM) accounts for approximately $3 \%$ of all human cancers and causes approximately $80 \%$ of skin cancer-related deaths. The lifetime risk of developing invasive CMM is currently estimated to be approxiamtely 1/50 (12). Melanomas with deep local invasion or those that have spread to the lymph nodes may be treated with surgery, immunotherapy, chemotherapy and/or radiation therapy. However, melanoma is likely to spread to other parts of the body. The 5- and 10-year relative survival rates for patients melanoma are 91 and $89 \%$, respectively (13). Patients with tumors that have spread to the tumor-draining lymph nodes have a high risk of recurrence following surgery. Thus, once melanoma metastasizes, the prognosis is often poor and therapeutic options are limited. Nevertheless, the prognosis of CMM is poor due to certain factors that are strongly associated with tumor cell proliferation and invasion. In recent years, special attention has been paid to the ISL1 protein and its participation in the migration process of cancer cells. Therefore, in the present study, ISL1 was selected as a novel biological marker with an aim to explore its roles in the proliferation, invasion, and apoptosis of melanoma cells. 


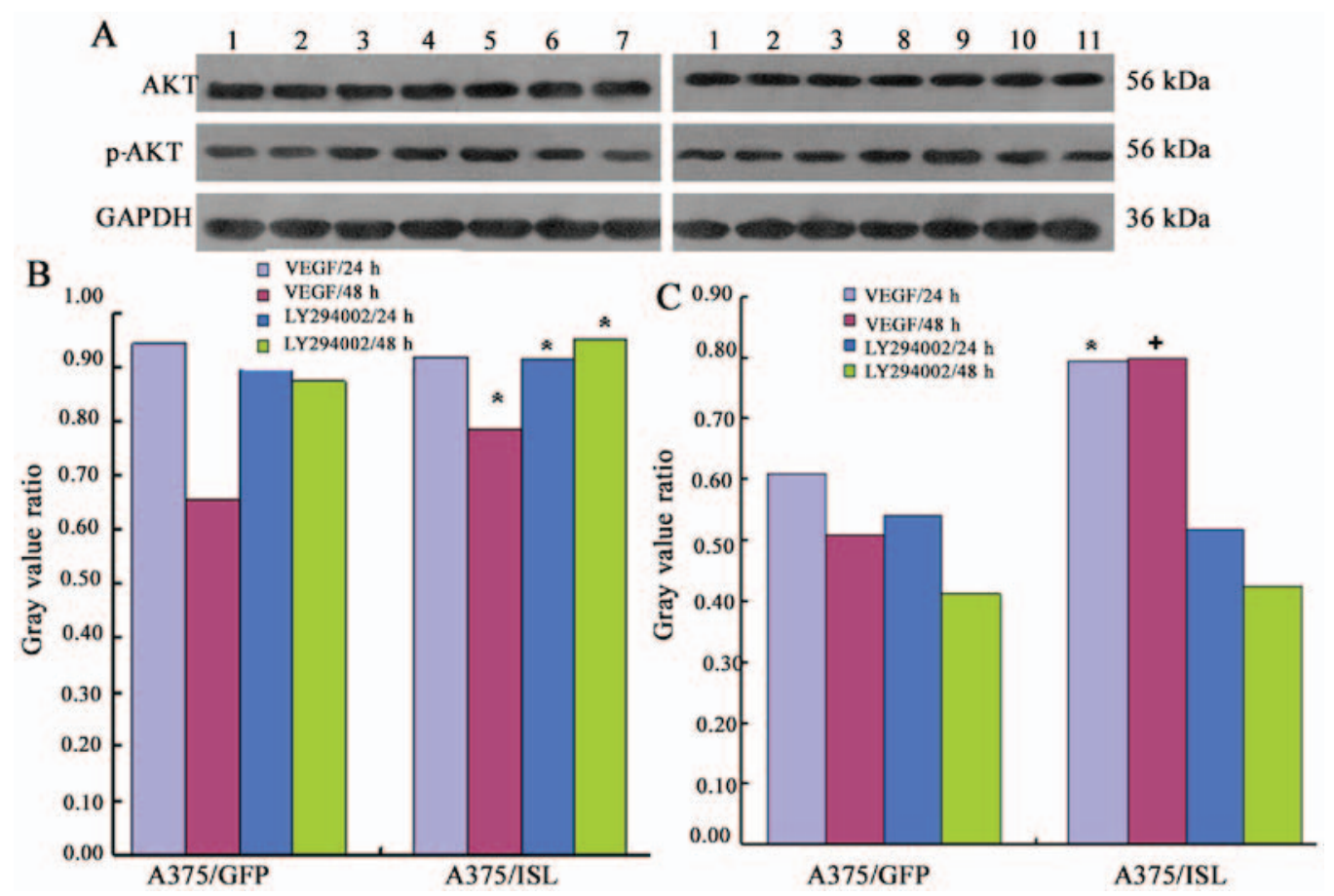

Figure 11. Expression of effect of insulin gene enhancer-binding protein (ISL1) on the activation of the phosphatidyliositol 3-kinase (PI3K)/Akt pathway. (A) The A375/ISL cells (transfected with ISL1 overexpression vector) and control cells (A375/GFP were treated with VEGF and the PI3K inhibitor, LY294002 for 24 and $48 \mathrm{~h}$, and the levels of Akt and p-Akt were then determined by western blot analysis. The lanes are as follows: lane 1, A375 cells; lane 2, A375/GFP cells; lane 3, A375/ISL cells; lane 4, A375/ISL cells treated with VEGF for $24 \mathrm{~h}$; lane 5, A375/ISL cells treated with VEGF for 48 h; lane 6, A375/ISL cells treated with LY294002 for $24 \mathrm{~h}$; lane 7, A375/ISL cells treated with LY294002 for $48 \mathrm{~h}$; lane 8, A375/GFP cells treated with VEGF for 24 h; lane 9, A375/GFP cells treated with VEGF for 48 h; lane 10, A375/GFP cells treated with LY294002 for 24 h; lane 11, A375/GFP cells treated with LY294002 for 48 h. (B and C) Quantitative analysis of the results shown in panel A. (A) Akt and (B) p-Akt levels in the A375/ISL cells and A375/GFP cells treated with VEGF and LY294002. The levels of Akt and p-Akt in the A375/ISL cells treated with VEGF for $48 \mathrm{~h}$ were markedly higher than those in the A375/GFP cells [(B) Akt: ${ }^{*} \mathrm{P}<0.05$; (C) p-Akt: $\left.{ }^{+} \mathrm{P}<0.001\right]$. The levels of Akt in the A375/ISL cells treated with the LY294002 inhibitor for 24 and $48 \mathrm{~h}$ were also significantly increased compared with those in the A375/ GFP cells $(\mathrm{P}<0.05)$.

First, we examined the effects of ISL1 on the proliferation of A375 cells. The results of MTT assay revealed that the OD value of A375/ISL cells was markedly higher than that of the A375/GFP and A375 cells following culture for $12 \mathrm{~h}$, and the difference was more conspicuous with a longer culture time. Furthermore, flow cytometry and TUNEL assay also revealed that ISL1 inhibited the apoptosis of the A375 cells. Importantly, ISL1 overexpression was associated with a decreased cell population in the G0/G1 phase and an increased cell population in the $\mathrm{S}$ and $\mathrm{G} 2 / \mathrm{M}$ phases. These results suggest that ISL1 promotes the proliferation of A375 cells. ISL1, which contains one DNA-binding site and two LIM domains, is a subtype of the LIM-homeodomain transcription factor subfamily and is mainly expressed in adult islet endocrine cells $(\alpha, \beta, \gamma$ and $\varepsilon)$, as well in the central nervous system (4). Moreover, ISL1 is also a transcription factor involved in pancreatic islet cell embryogenesis, thus suggesting that it could be utilized as a sensitive marker for pancreatic islet cells and their neoplasms (14). However, it is not clear whether ISL1 plays important roles in the regulation of endocrine hormone secretion in post-natal pancreatic islets. It has been demonstrated that ISL1 is required for the proliferation, migration and survival of cardiac progenitor cells (15). It also promotes the proliferation and repair of injured motor neurons (16). Furthermore, other researches have indicated that ISL1 promotes the proliferation of mature pancreatic islet cells and attenuates cell apoptosis against oxidative stress by activating c-Myc and cyclin D1 transcription by directly binding to its promoters (17). Conversely, some researchers have observed that transgenic mice overexpressing ISL1 in the endocrine pancreas exhibit an increased $\beta$-cell function without enhanced $\beta$-cell proliferation and without increased apoptosis (18). Others have also determined that ISL1 cells and even pacemaking cells do not exhibit proliferative activity at higher rates than those of normal cardiac myocytes in the adult heart under normal conditions (19).

In this study, we also examined the effects of ISL1 on the invasive ability of A375 cells by conducting penetration experiments on Transwell chambers coated with Matrigel. We observed that a higher number of A375/ISL cells penetrated the Matrigel compared with that of A375/GFP and A375 cells. The average penetration rate of A375/ISL cells was higher than that of the A375/GFP and A375 cells. These findings indicated that the overexpression of ISL1 promoted the invasion of A375 cells. It has been previously demonstrated that ISL1 and penetratin peptides efficiently internalize into human Bowes melanoma cells through the translocation property of the cell-penetratin peptide and the native Cys residue in the ISL1 sequence (20). Of note, some researchers have suggested that ISL1 and PAX8 may be utilized as immunohistochemical markers for pancreatic NETs to promote the formation of tumors (21). Due to the limited number of relevant studies on this topic, the mechanisms underlying its pathogenesis remain unclear. 
In this study, to explore the mechanisms underlying the capacity of ISL1 to promote the invasion of A375 cells, the expression levels of MMP-2 and MMP-9 were examined. The resutls of qPCR and western blot analysis indicated that ISL1 upregulated the mRNA and protein expression levels of MMP-2 and MMP-9 in the A375 cells. Several molecules are involved in tumor invasion, such as MMPs. MMPs are a family of related enzymes that degrade the extracellular matrix. The activation of these enzymes provides tumor cells access to the vasculature, invade target organs, and facilitate metastases. Although MMP-2 and MMP-9 are associated with various types of cancer, the mechanisms underlying the upregulation of MMP-2 and MMP-9 in the A375/ISL cells were not yet fully elucidated.

Subsequently, we examined whether ISL1 exerts its effects on the A375 cells via the Akt pathway by conducting western blot analysis. Treatment of the cells with VEGF for $48 \mathrm{~h}$ significantly increased the Akt and p-Akt levels in the A375/ ISL cells compared with the A375/GFP cells. In addition, treatment with the LY294002 inhibitor for 24 and $48 \mathrm{~h}$ also significantly increased the levels of Alt in the A375/ISL cells compared with the A375/GFP cells. Our data suggest that the overexpression of ISL1 promotes the proliferation of A375 melanoma cells via the Akt pathway. Some researchers have supported the pro-angiogenic effects of ISL1 transduction by demonstrating an increase in the expression of the proangiogenic cytokine, VEGF (22). The overexpression of ISL1 in endothelial cells and mesenchymal stem cells promotes blood vessel formation. Other studies have suggested that ISL1 promotes post-natal angiogenesis and vasculogenesis by improving the angiogenic properties of endothelial cells and mesenchymal stem cells (23). However, studies describing ISL1 in relation to LY294002 are limited. Several studies have shown that the cultivation of human pancreatic cells in a differentiation medium supplemented with LY294002 stimulates the expression of insulin mRNA and protein, which in turn leads to the enrichment of pancreatic stem cells that are capable of self-renewal and endocrine differentiation (24). Therefore, we speculate that the PI3K/Akt signaling pathway, in close association with ISL1, promote the invasion of A375 cells, although the exact mechanisms involved remain unclear.

The present study determined that ISL1 promotes the proliferation and invasion, and inhibits the apoptosis of A375 cells, and these findings may be utilized in determining the biological function in ISL1 in melanoma. In vivo experiments examining the effects of ISL1 on patients with melanoma were not included in the present study, which is therefore a limitation of the present study. In the future, we aim to collect and examine clinical samples to further explore the role of ISL1 in the proliferation, invasion and apoptosis of melanoma. It may also be helpful to determine whether ISL1 may be used as a novel molecular target for the treatment of melanoma to improve the survival rate of patients.

In conclusion, the data from the present study demonstrated that the overexpression of ISL1 promoted the proliferation and invasion of A375 cells. More importantly, the overexpression of ISL1 inhibited the apoptosis of the A375 melanoma cells, increased the number of cells in the $S$ phase, and decreased the number of cells in the G0/G1 phase of the cell cycle. Moreover, ISL1 upregulated the mRNA and protein expression levels of
MMP-2 and MMP-9 in the A375 cells, which in turn promoted cell invasion. Thus, from the findings of the present study, it is suggested that ISL1 plays an important role in A375 cells via the PI3K/Akt signaling pathway.

\section{Acknowledgements}

The authors would like to thank the members of the laboratory of Wei Si Teng Co. in Chongqing, China for their assistance with conducting this research.

\section{Funding}

The study was supported by a grant from the Health and Family Planning Commission in Heilongjiang province in China (No. 2017-204).

\section{Availability of data and materials}

The analyzed datasets generated during the study are available from the corresponding author on reasonable request.

\section{Authors' contributions}

$\mathrm{XZ}$ performed the experiments and writing the manuscirpt; QM designed the experiments and YL generated the data.

\section{Ethics approval and consent to participate}

Not applicable.

\section{Consent for publication}

Not applicable.

\section{Competing interests}

The authors declare that they have no competing interests.

\section{References}

1. Misu M, Ouji Y, Kawai N, Nishimura F, Nakamura-Uchiyama F and Yoshikawa M: Effects of Wnt-10b on proliferation and differentiation of murine melanoma cells. Biochem Biophys Res Commun 463: 618-623, 2015

2. Raghunath A, Sambarey A, Sharma N, Mahadevan U and Chandra N: A molecular systems approach to modelling human skin pigmentation: identifying underlying pathways and critical components. BMC Res Notes 8: 170, 2015.

3. Siegel R, Ma J, Zou Z and Jemal A: Cancer statistics, 2014. CA Cancer J Clin 64: 9-29, 2014.

4. Karlsson O, Thor S, Norberg T, Ohlsson H and Edlund T: Insulin gene enhancer binding protein Isl-1 is a member of a novel class of proteins containing both a homeo- and a Cys-His domain. Nature 344: 879-882, 1990.

5. Nasif S, de Souza FS, González LE, Yamashita M, Orquera DP, Low MJ and Rubinstein M: Islet 1 specifies the identity of hypothalamic melanocortin neurons and is critical for normal food intake and adiposity in adulthood. Proc Natl Acad Sci USA 112: E1861-E1870, 2015.

6. Cai CL, Liang X, Shi Y, Chu PH, Pfaff SL, Chen J and Evans S: Isl1 identifies a cardiac progenitor population that proliferates prior to differentiation and contributes a majority of cells to the heart. Dev Cell 5: 877-889, 2003.

7. Huber GF: Modern management of Merkel cell carcinoma. Curr Opin Otolaryngol Head Neck Surg 22: 109-115, 2014. 
8. Agaimy A, Erlenbach-Wünsch K, Konukiewitz B, Schmitt AM, Rieker RJ, Vieth M, Kiesewetter F, Hartmann A, Zamboni G, Perren A, et al: ISL1 expression is not restricted to pancreatic well-differentiated neuroendocrine neoplasms, but is also commonly found in well and poorly differentiated neuroendocrine neoplasms of extrapancreatic origin. Mod Pathol 26: 995-1003, 2013.

9. Su X, Wang P, Wang X, Cao B, Li L and Liu Q: Apoptosis of U937 cells induced by hematoporphyrin monomethyl ether-mediated sonodynamic action. Cancer Biother Radiopharm 28: 207-217, 2013.

10. Hao Q, Li W, Zhang C, Qin X, Xue X, Li M, Shu Z, Xu T, $\mathrm{Xu}$ Y, Wang W, et al: TNFa induced FOXP3-NFאB interaction dampens the tumor suppressor role of FOXP3 in gastric cancer cells. Biochem Biophys Res Commun 430: 436-441, 2013.

11. Livak KJ and Schmittgen TD: Analysis of relative gene expression data using real-time quantitative PCR and the 2(-Delta Delta C(T)) method. Methods 25: 402-408, 2001.

12. Piérard-Franchimont $C$, Hermanns-Lê $T$, Delvenne $P$ and Piérard GE: Dormancy of growth-stunted malignant melanoma: sustainable and smoldering patterns. Oncol Rev 8: 252, 2014.

13. Aris M and Barrio MM: Combining immunotherapy with oncogene-targeted therapy: a new road for melanoma treatment. Front Immunol 6: 46, 2015.

14. Graham RP, Shrestha B, Caron BL, Smyrk TC, Grogg KL, Lloyd RV and Zhang L: Islet-1 is a sensitive but not entirely specific marker for pancreatic neuroendocrine neoplasms and their metastases. Am J Surg Pathol 37: 399-405, 2013.

15. Bu L, Jiang X, Martin-Puig S, Caron L, Zhu S, Shao Y, Roberts DJ, Huang PL, Domian IJ and Chien KR: Human ISL1 heart progenitors generate diverse multipotent cardiovascular cell lineages. Nature 460: 113-117, 2009.

16. Shi Y, Zhao S, Li J and Mao B: Islet-1 is required for ventral neuron survival in Xenopus. Biochem Biophys Res Commun 388 : 506-510, 2009
17. Guo T, Wang W, Zhang H, Liu Y, Chen P, Ma K and Zhou C: ISL1 promotes pancreatic islet cell proliferation. PLoS One 6: e22387, 2011.

18. Ediger BN, Du A, Liu J, Hunter CS, Walp ER, Schug J, Kaestner KH, Stein R, Stoffers DA and May CL: Islet-1 is essential for pancreatic $\beta$-cell function. Diabetes 63: 4206-4217, 2014.

19. Weinberger F, Mehrkens D, Starbatty J, Nicol P and Eschenhagen T: Assessment of DNA synthesis in Islet- $1^{+}$cells in the adult murine heart. Biochem Biophys Res Commun 456: 294-297, 2015.

20. Kilk K, Magzoub M, Pooga M, Eriksson LE, Langel U and Gräslund A: Cellular internalization of a cargo complex with a novel peptide derived from the third helix of the islet-1 homeodomain. Comparison with the penetratin peptide. Bioconjug Chem 12: 911-916, 2001.

21. Koo J, Mertens RB, Mirocha JM, Wang HL and Dhall D: Value of Islet 1 and PAX8 in identifying metastatic neuroendocrine tumors of pancreatic origin. Mod Pathol 25: 893-901, 2012.

22. Ferrara N, Carver-Moore K, Chen H, Dowd M, Lu L, O'Shea KS, Powell-Braxton L, Hillan KJ and Moore MW: Heterozygous embryonic lethality induced by targeted inactivation of the VEGF gene. Nature 380: 439-442, 1996.

23. Barzelay A, Ben-Shoshan J, Entin-Meer M, Maysel-Auslender S, Afek A, Barshack I, Keren G and George J: A potential role for islet-1 in post-natal angiogenesis and vasculogenesis. Thromb Haemost 103: 188-197, 2010.

24. Linning KD, Tai MH, Madhukar BV, Chang CC, Reed DN Jr, Ferber S, Trosko JE and Olson LK: Redox-mediated enrichment of self-renewing adult human pancreatic cells that possess endocrine differentiation potential. Pancreas 29: e64-e76, 2004. 